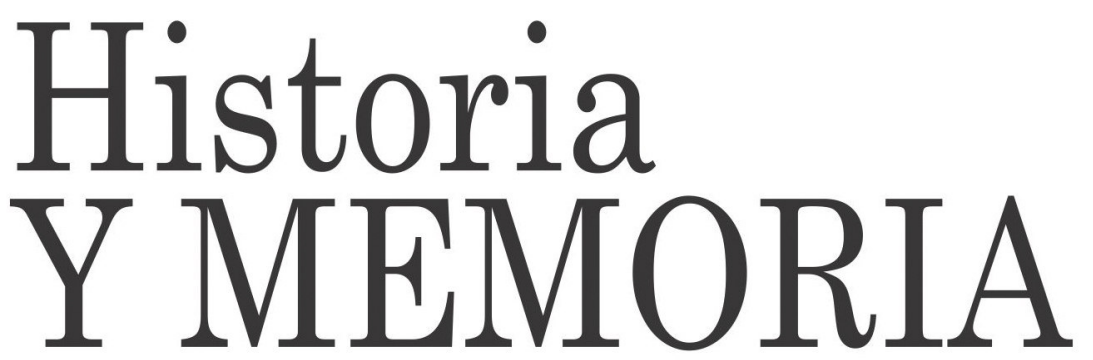

Abdón Cifuentes, un publicista católico frente al Estado liberal. Chile, 1862-1890

Francisco Alejandro Garcia Naranjo Páginas: 297 - 338 


\title{
Abdón Cifuentes, un publicista católico frente al Estado liberal. Chile, 1862-1890*
}

\author{
Francisco Alejandro García Naranjo ${ }^{1}$ \\ Universidad Michoacana de San Nicolás \\ de Hidalgo-México
}

Recepción: 20/11/2013

Evaluación: 02/12/2013

Aceptación: 31/01/2014

Artículo de Investigación e Innovación.

\section{Resumen}

El objetivo de este trabajo es mostrar la trayectoria de Abdón Cifuentes (1836-1928), uno de los líderes del partido conservador de la segunda mitad del siglo XIX, chileno, que como católico y republicano combatió al anticlericalismo liberal de su época, a la vez que luchó en los terrenos de la prensa, el Parlamento y el activismo social, todo ello para arrancarle garantías y derechos al estado liberal en favor de su idea de sociedad, basada en el ideal católico. Para ello se presenta un esbozo de la trayectoria pública de este

\footnotetext{
* Este artículo es producto del proyecto de investigación titulado: Abdón Cifuentes, soldado de la iglesia.

política y religión en Chile a fines del siglo XIX, financiado por la Universidad Michoacana de San Nicolás de Hidalgo-México.

1 Doctor en Historia, Universidad Pablo de Olavide, Sevilla-España. Integrante Grupo de Investigación Cuerpo Académico Economía, Cultura y pensamiento en México y América Latina. Líneas de investigación: Geografía, economía y región en México y América Latina; Historia del Estado, las ideas y las instituciones en México y América Latina. pacognaranjo@gmail.com.
} 
publicista católico conservador, reseñando su actuación. La siguiente sección, "construyendo máquinas de guerra" se ocupa de mostrar los referentes y las batallas de Cifuentes para generar una ciudadanía católica informada a través de la promoción de la prensa del mismo signo en gran parte de Chile entre los años de 1862 y 1885. "Activismo católico-social" trata del incansable impulso de Cifuentes por instruir y organizar a la sociedad católica en Chile, creando desde 1865 distintas asociaciones que congregaban jóvenes, obreros, miembros de la élite en labores de beneficencia social, y luego una gran Unión Católica que desde lo social se opuso a la desacralización de matrimonio y cementerios entre 1883 y 1888. Al final se presentan unas conclusiones.

Palabras clave: partido conservador, periodismo católico, Estado liberal, asociacionismo católico, anticlericalismo.

\title{
Abdón Cifuentes, Catholic advertiser vs. the Liberal State, 1862-1890.
}

\begin{abstract}
This study is intended to trace the trajectory of Abdón Cifuentes (1836-1928), a Catholic-Conservative Chilean political leader of the second half of the XIX century. As a Catholic and Republican, Cifuentes struggled against liberal anticlericalism, as well as the press, the Parliament and the social activism of that time. Cifuentes asserted his idea of society, based on the Catholic ideal whereby the Liberal State should be removed of its guarantees and rights. In order to know more about the main aspects of this Catholic-Conservative advertiser, an outline of his trajectory is presented in this article. The following section, "Building war machines" deals with the referents and
\end{abstract}


struggles of Cifuentes to keep Catholic citizens in a large part of the country informed by means of the promotion of the Conservative press between 1862 and 1885. "SocialCatholic activism" is the result of Cifuentes' unending will to instruct and organize Chilean Catholic society. Thus, since 1865, different associations encompassing youth, workers, members of the elite engaged social and charity work, and the great Catholic Union was created to oppose the desacralization of marriage and cemeteries, between the years of 1883 and 1888. Conclusions are drawn at the end of this study.

Key words: Conservative party, Catholic journalism, Liberal State, catholic associations, anticlericalism.

\section{Abdón Cifuentes, un publiciste catholique face à l'État libéral. Le Chili, 1862-1890}

\section{Résumé}

Cet article cherche à décrire la trajectoire d'Abdón Cifuentes (1836-1928), l'un des leaders du parti conservateur chilien de la deuxième moitié du XIX ${ }^{\mathrm{e}}$ siècle. Catholique et républicain, Cifuentes a combattu l'anticléricalisme libéral de son époque en même temps qu'il a combattu dans la presse, au Parlement et par l'activisme social afin que l'État libéral respecte les garanties et les droits, pour faire avancer son projet de société fondée sur l'idéal catholique. Cet article présente d'abord une ébauche de la trajectoire publique de ce publiciste. La partie suivante montre les fondements doctrinaux et les efforts de Cifuentes pour former une citoyenneté catholique informée, au moyen de la promotion de la presse de sa sensibilité politique, dans une grande partie du Chili pendant la période 1862-1885. Le passage intitulé Activisme catholico-social traite du travail tenace de Cifuentes pour instruire et pour organiser 
la société catholique au Chili, par la création dès 1865 de plusieurs associations réunissant des jeunes, des ouvriers et des membres de l'élite, dans des travaux d'assistance sociale, et par la suite, d'une grande Union catholique qui s'est opposée à la désacralisation du mariage et des cimetières entre 1883 et 1888.

Mots clés: Parti conservateur, Journalisme catholique, État libéral, Militantisme catholique, Anticléricalisme.

\section{Abdón Cifuentes: "soldado de la iglesia"2}

Abdón Cifuentes nació el 16 de mayo de 1836 en San Felipe de Aconcagua y murió 14 de abril de 1928 en Santiago. Desde muy joven dio muestras de su vocación de servicio y del arraigo de sus convicciones religiosas, pues en 1855 ingresó a las Conferencias de San Vicente de Paul y perteneció a ésta institución de socorro a los pobres a lo largo de 55 años. ${ }^{3}$ Se graduó de abogado en julio de 1861, profesión a la que se dedicó al mismo tiempo que a sus clases. ${ }^{4}$ En 1862 fungió como profesor del Instituto Nacional, función en la que se mantuvo hasta $1892 .{ }^{5}$ Cifuentes formó parte del partido conservador, (fundado en 1857 como resultado de una disputa de atribuciones entre la Corte Suprema y la Iglesia, trayendo la división de la élite conservadora que gobernaba desde 1831). El partido conservador inicialmente estuvo apegado al clero y con posterioridad, con la llegada de Cifuentes y otros jóvenes,

\footnotetext{
${ }^{2}$ La expresión es de: Abdón Cifuentes, R. B. Gumucio, (recopilación e introducción), Colección de discursos de don Abdón Cifuentes (Chile: Establecimiento poligráfico Roma, 1897-1898), T. I, 266.

${ }^{3}$ Abdón Cifuentes, Memorias (Chile: Editorial Nascimento, 1936), T. I, 3839.

${ }^{4}$ Don Abdón Cifuentes: homenaje a su memoria (Chile: Editorial La Ilustración, 1928), 5.

${ }^{5}$ Abdón Cifuentes, Memorias,... T. I, 59. 
modificaría sus referentes para defender el catolicismo y a la vez combatir el autoritarismo presidencial y propender por reformas republicanas y liberalizantes. En 1861 el partido conservador se aliaría al recién fundado partido liberal para combatir al partido nacional, que preparaba la sucesión presidencial (partido este último, que creara el presidente Manuel Montt en 1857). La alianza entre conservadores y liberales provocó un desprendimiento de inconformes del partido liberal, así se constituyó el partido radical. ${ }^{6}$

Entre 1862 y 1867 Cifuentes escribió para los diarios El Bien Público y El Independiente. 1865 fue un año significativo en la trayectoria pública de Cifuentes, pues pronunció su discurso sobre el derecho electoral de la mujer en una de las muchas sociabilidades católicas y literarias que él mismo ayudó formar. ${ }^{7}$ El discurso en sí mismo tiene su trascendencia para la historia de la ampliación del sufragio en Chile y muestra, además, el genuino compromiso de Cifuentes con la libertad y la igualdad de derechos. Asimismo, dicho discurso apareció como columna editorial de El Independiente. ${ }^{8}$

Hacia los últimos meses de 1869 , en medio de sus numerosas actividades como lo eran la subsecretaría de Relaciones Exteriores (nombrado en 1867), su cargo de diputado $^{9}$ (elegido en 1865), el profesorado y la defensa de una que otra causa en los tribunales, Cifuentes vio

\footnotetext{
6 Simon Collier y W.F. Sater, Historia de Chile. $1808-1994$ (España: Cambridge University, 1998), 96-115.

7 R. B. Gumucio, (recopilación e introducción), Colección de discursos, T. I, 138 .

8 "El derecho electoral de la mujer I", El Independiente, Santiago, 23 agosto de 1865.

9 Germán Urzúa Valenzuela, Historia política de Chile y su evolución electoral (desde 1810 a 1992) (Chile: Editorial Jurídica de Chile, 1992) 205. Cfr.: Suplemento al Independiente (sic), Santiago, 15 de abril de 1867.
} 
deteriorada su salud y por consejo médico, debió salir de Chile en un largo viaje. ${ }^{10}$ Para ello, contó con una licencia del gobierno y la comisión de visitar los consulados y mejorar su funcionamiento. Además, recibió la invitación para realizar el viaje con los obispos que se dirigían a Europa para asistir al Concilio Vaticano. Así, se embarcó en septiembre de 1869 y regresó a Chile en marzo de 1871. Este viaje fue "decisivo en la formación de su personalidad intelectual", pues junto con su fuerte catolicismo tenía "simpatías dormidas por el temperamento y el carácter yanqui", ${ }^{11}$ en especial por sus instituciones. A ese respecto, las Memorias de Abdón Cifuentes publicadas en 1936 relatan las impresiones de este viaje. Del viaje a los Estados Unidos (luego de haber recorrido Francia, Italia, España, Inglaterra, Bélgica y Alemania), le impactó profundamente el poder de la iniciativa privada que no pedía nada al gobierno en materia educativa. "El espectáculo de los asombrosos frutos de la libertad de enseñanza de los Estados Unidos me llenó de satisfacción por haber sido el primero que en Chile defendiera esa preciosa libertad". ${ }^{12}$

Tales fueron los temas vitales para Abdón Cifuentes: libertad, educación y religión. De la misma manera que fueron los ejes de su acción política, en la que estaba claro que el gran enemigo del conservadurismo era el Estado controlado mayoritariamente por el liberalismo. Cifuentes encontró apoyo en otros miembros del partido conservador, también parlamentarios, como Manuel José Irarrázaval, Zorobabel Rodríguez, Carlos Walker Martínez y Enrique Tocornal. Todos estos políticos se caracterizaron

\footnotetext{
10 Véase: "Banquete en honor del diputado por Rancagua don Abdón Cifuentes", El Independiente, Santiago, 8 de septiembre de 1869 y "Banquete de despedida en honor del señor don Abdón Cifuentes", El Independiente, Santiago, 10 de septiembre de 1869.

${ }_{11}$ Francisco A. Encina, Historia de Chile: texto original completo (Chile: Editorial Nascimento, 1940) t., XXVIII, 238.

${ }^{12}$ Francisco A. Encina, Historia de Chile, T. XXVIII,... 239.
} 
por asumir posiciones liberalizantes en lo que al régimen político se refiere, para así tratar de disputarle a los liberales espacios en la vida pública, al mismo tiempo que tuvieron una posición independiente respecto a la jerarquía católica.

En 1870, aún ausente del país, Cifuentes fue reelegido diputado por Rancagua. ${ }^{13}$ Para febrero de 1871 él estaba de regreso en Chile. Poco después, reasumió su puesto de subsecretario de Relaciones Exteriores y su lugar como profesor del Instituto Nacional. Volvió a la jefatura de la "Sociedad de Amigos del País" a la que involucró en la contienda presidencial que habría de elegir presidente al liberal Federico Errázuriz (18711876) con el importante apoyo del partido conservador y el beneplácito de la jerarquía eclesiástica. En septiembre de 1871 Abdón Cifuentes se convirtió en ministro de justicia, culto e instrucción como resultado de la negociación entre los conservadores y los liberales, y el propio Federico Errázuriz (sobrino del arzobispo Valdivieso), elegido presidente de la República ese mismo año apoyado por la fusión liberal-conservadora (paradójica alianza formada en 1861 que acumulaba tensiones ideológicas y profundos desacuerdos sobre el mejor rumbo para el país). Desde su nuevo cargo de gobierno, éste "paladín de la libertad de enseñanza"14 se propuso llevar a cabo las reformas que consideraba indispensables en el tema educativo, largamente maduradas desde sus años como docente y que luego de su estadía en Estado Unidos, se convirtieron para él en necesidades impostergables para el progreso del país.

Durante el tiempo que Cifuentes ejerció el ministerio se presentaron hechos que pusieron a prueba su capacidad

\footnotetext{
${ }^{13}$ Germán Urzúa Valenzuela, Historia política de Chile,... 216.

${ }^{14}$ La expresión es de: Max Martínez M., Semblanzas chilenas. Primera serie. Próceres pelucones (Santiago: Imprenta La Cruz, 1948), 145.
} 
de resolución y sus firmes convicciones sobre las libertades políticas, los cuales evidenciaron cada vez más y de forma creciente, el cambio que se venía gestando en la vida pública de Chile, cuya dirección era el laicismo y la liberalización, empujados por los presidentes liberales que desde 1861 gobernaban en país y a despecho del partido conservador, que veía sin embargo cómo el anticlericalismo tomaba fuerza. Eran los preludios del conflicto religioso que incendiarían la escena política andando los años, que dividiría al país entre anticlericales y clericales. Fue así cuando a finales de 1871 se presentó un conflicto entre el intendente (liberal) de Concepción y el obispo de dicha provincia por el entierro de un viejo militar enterrado en sagrado, cuando toda su vida la pasó contraviniendo las leyes católicas. ${ }^{15}$ Fue un choque entre el poder religioso y civil que desató una tormenta en el Parlamento, y que Cifuentes supo enfrentar. Su discurso ${ }^{16}$ en el Congreso rebatió el voto de censura que se promoviera en su contra. ${ }^{17}$ Enseguida, el Gobierno expidió un decreto sobre cementerios que resolvía la cuestión planteada por la muerte de disidentes o incrédulos siendo los cementerios parroquiales en su mayoría. Cifuentes explica en sus Memorias que en ese decreto logró que se incorporaran artículos que contemplaban el establecimiento de cementerios de propiedad particular "a imitación de la libertad que había observado en Estados Unidos”. ${ }^{18}$

El gran tema para Cifuentes era la libertad de enseñanza y estaba deseoso de hacer que Chile siguiera la senda de otras naciones que en su particular mirada

\footnotetext{
${ }^{15}$ Ricardo Donoso, Las Ideas políticas de Chile (México: FCE, 1946) 247-248. ${ }^{16}$ Véase: R. B. Gumucio, (recopilación e introducción), Colección de discursos, T. I,... 359-373.

17 "Congreso Nacional. Cámara de diputados. Sesión 33 extraordinaria en 14 de diciembre de 1871”, El Independiente, Santiago, 15 de diciembre de 1871.

${ }^{18}$ Abdón Cifuentes, Memorias, T. ... II, 6.
} 
llevaban la delantera en los terrenos de las ciencias y las artes, proyecto que esperaba hacer realidad como ministro de Instrucción y que nacía del conocimiento que había adquirido de sus observaciones de otras experiencias educativas y de las legislaciones de países como Francia, Estados Unidos, Bélgica Inglaterra y Alemania. El propósito de Cifuentes, del partido conservador y de la misma jerarquía eclesiástica, era decretar la libertad de exámenes para que los establecimientos de educación sostenidos por la Iglesia y particulares estuvieran libres de la supervisión del Estado.

El decreto que daba forma a los planteamientos del ministro Cifuentes fue promulgado a mediados de enero de 1872. De la misma manera desarrolló otras iniciativas tendientes a mejorar el estado del ramo en el país, ${ }^{19}$ como implantar el profesorado femenil en las escuelas primarias a semejanza del que vio en Estados Unidos. Reforma que llevó adelante pese a la oposición de los "apóstoles liberales de la enseñanza". ${ }^{20}$ Todas estas medidas aportan evidencias de las concepciones modernas y renovadoras de la visión de Cifuentes sobre la educación y su misión para el progreso del país. No obstante, las reacciones no se hicieron esperar. Cifuentes lo describió muy bien en sus Memorias:

Los monopolistas tocaron a generala a todas las preocupaciones de secta, a todas las pasiones políticas, a todas las rencillas de aldea, a todas las timideces de la ignorancia contra el Ministro que había alzado la noble bandera de la libertad. No dejaron invención que no urdieron, mentira que no forjaron, calumnia que no propalaron contra el Ministro. Este quería matar al Instituto [Nacional],

\footnotetext{
${ }^{19}$ Abdón Cifuentes, Memorias, T. II... 28.

${ }^{20}$ La expresión es de: Francisco A. Encina, Historia de Chile, T. XXIX,... 72.
} 
quería matar al Estado docente, quería matar la ilustración en Chile, El rector del Instituto y el secretario general del Consejo de la Universidad,[...] se pusieron a la cabeza de esta cruzada contra la libertad. La cosa parecía natural; eran caudillos del liberalismo chileno. ${ }^{21}$

Fue grande la agitación política por las implicaciones del decreto. ${ }^{22}$ Se generaron tensiones entre conservadores y liberales del gobierno, se presentaron desórdenes estudiantiles en el Instituto Nacional y apasionados debates en el Congreso. ${ }^{23}$ Cifuentes, como ministro de Instrucción, fue interpelado a mediados de junio de 1873 en el Congreso por los sucesos. Al final, la Cámara de Diputados votó la aprobación de la conducta del ministro y del gobierno, rechazando la censura propuesta. ${ }^{24}$

Abdón Cifuentes renunció al ministerio luego de terminado el debate en el que salió vencedor. A raíz de ello, se dio la retirada de los conservadores del gobierno, los cuales pasaron a la oposición y así llegó a su fin la fusión liberal-conservadora. ${ }^{25}$ Cifuentes y el resto de los conservadores, así como la jerarquía eclesiástica, continuaron defendiendo la libertad de enseñanza como un derecho natural de la familia y un derecho político de todo ciudadano. La mayor concreción de las aspiraciones católicas y conservadoras sobre la libertad de enseñanza de la época fue la creación de la Universidad Católica el 8

\footnotetext{
$\overline{{ }^{21}}$ Abdón Cifuentes, Memorias, T. II,... 27.

22 "Revista de la prensa", El Independiente, Santiago, 17 de junio de 1873.

${ }^{23}$ Simon Collier y W.F. Sater, Historia de Chile,... 116.

${ }^{24}$ Véase: R. B. Gumucio, (recopilación e introducción), Colección de discursos, T. I, 391-465.

${ }^{25}$ Véase: Sol Serrano, Universidad y nación. Chile en el siglo XIX (Santiago: Editorial Universitaria, 1994).
} 
de septiembre de $1888 .^{26}$ Uno de los fundadores fue Abdón Cifuentes, al lado de la jerarquía eclesiástica. ${ }^{27}$

Pasados unos meses desde su salida del gobierno, Cifuentes retomó su cátedra de historia en el Instituto Nacional, así como también reabrió su estudio de abogado. No dejó de ser miembro del Congreso, puesto que había sido elegido diputado por Santiago ${ }^{28}$ hacía unos cuantos meses, en las elecciones de diputados y de electores de senadores. En los años siguientes se dedicó a promover con mayor fuerza el asociacionismo entre la juventud, las clases dirigentes y el mundo obrero, con entero beneplácito de la jerarquía eclesiástica. Así como a la fundación de nuevos diarios católicos y una intensa campaña entre conservadores y católicos para reunir fondos para el sostenimiento de El Independiente.

En diciembre de 1878 Cifuentes pronunció el discurso de inauguración de la Gran Convención Conservadora. ${ }^{29}$ Asamblea en la que el partido conservador reunió a todos sus correligionarios en donde se fijó la posición del partido respecto a los grandes temas nacionales. En 1879 Cifuentes volvió a ser elegido diputado. ${ }^{30}$ En 1883 fundó la Unión Católica a solicitud de la iglesia católica ${ }^{31}$ para crear un movimiento social que amparara a la iglesia de las hostilidades del gobierno liberal de Domingo Santa María

\footnotetext{
26 "Solemne asamblea para iniciar los trabajos de la Universidad Católica celebrada en el gran salón de la Unión Central, el 8 de septiembre de 1888", El Independiente, Santiago, 9 de septiembre de 1888.

${ }^{27}$ Nicolás Cruz y Pablo Whipple, Nueva historia de Chile. Desde los orígenes a nuestros días (Santiago: Zig-Zag, 1997), 348.

${ }^{28}$ Germán Urzúa Valenzuela, Historia política de Chile,... 227.

${ }^{29}$ El Independiente, Santiago, 24 de diciembre de 1878. Véase también: Abdón Cifuentes, Colección de discursos, T. II, 27-46.

${ }^{30}$ Germán Urzúa Valenzuela, Historia política de Chile, 248. Véase también: Abdón Cifuentes, Memorias, T. II, 156-157.

${ }^{31}$ Don Abdón Cifuentes,... 13.
} 
(1881-1886), como reacción a la ruptura de relaciones entre el Estado chileno y el Vaticano. Entre 1883 y 1884, el gobierno chileno promulgó la ley de cementerios laicos, la ley de matrimonio civil y la ley de registro civil, desatando las iras católicas y eclesiásticas ${ }^{32}$ y la expansión de la Unión Católica, que tuvo una organización nacional y regional, coordinando a los laicos por sectores. ${ }^{33}$

Con la llegada del liberal José Balmaceda a la presidencia (1886-1891), fue cesando la pugna entre el clericalismo y el anticlericalismo a través de acuerdo entre el gobierno y la iglesia. Sin embargo, en los años siguientes surgió una nueva disputa, de orden constitucional, por la primacía entre el poder Ejecutivo y el Congreso, que desde décadas atrás venía acumulando mayores atribuciones en la marcha de la nación. Esta pugna fue deteriorando la vida política y generando una creciente oposición al presidente Balmaceda.

El escenario ensombrecido en 1890 sacó a Cifuentes de su alejamiento de la arena política. La batalla era ahora por la defensa de las libertades públicas y por el respeto de la constitucionalidad, banderas que el partido conservador seguía sosteniendo. La tensión política entre el poder presidencial yel poder parlamentario había traídoconstantes crisis ministeriales al gobierno de Balmaceda. El conflicto entre el presidente y el Congreso se agravó en 1890, cuando Balmaceda se negó a acceder a un nuevo cambio ministerial exigido por las mayorías parlamentarias. En consecuencia, el Congreso se negó a aprobar la ley de presupuestos hasta que el gobierno formase un nuevo ministerio.

\footnotetext{
${ }^{32}$ Para saber más de este proceso, véase: Marco Antonio León León, Sepultura sagrada, tumba profana. Los espacios de la muerte en Santiago de Chile, 1888-1988, (Santiago: Dibam, 1997).

${ }^{33}$ Véase: Abdón Cifuentes, Las Asociaciones católicas (Santiago: Imprenta de El Independiente, 1883).
} 
Tales hechos trajeron un creciente proceso de división y polarización, evidenciado en el atrincheramiento político de los dos bandos que ya se habían configurado. En el mes de julio de 1890 la oposición al presidente Balmaceda convocó a una multitudinaria manifestación en la capital del país, y en la que Cifuentes fue el orador que representó la opinión del partido conservador. ${ }^{34}$ Así lo recordó:

El 13 de julio se congregaba en el Teatro Santiago más de cuatro mil personas, de lo que tenía de más respetable la sociedad de Santiago, respondiendo a una invitación firmada por más de cien caballeros que ocupaban una posición superior en nuestro mundo social: senadores, consejeros de Estado, diputados ex Ministros, antiguos diplomáticos, escritores, industriales y muchos caracterizados representantes de todos los matices políticos. Por lo mismo que yo vivía alejado del Congreso, por no ser diputado, mis amigos me pidieron que hablase a nombre de nuestro partido, como lo hice, procurando conjurar la dictadura que se diseñaba claramente y acentuar la verdadera doctrina constitucional de nuestro gobierno parlamentario. Una comisión de caballeros llevó a Balmaceda a nombre de la Asamblea una respetuosa solicitud, suplicándole pusiera fin a la desastrosa situación del país, cambiando su ministerio. Balmaceda contestó negándose a ello con su vanidad y soberbia acostumbrada. $^{35}$

Las arbitrariedades del poder presidencial continuaron sin embargo. Dice Cifuentes en sus Memorias que él se encargó de hacer ver entre el resto de los dirigentes del partido conservador la necesidad de prepararse para resistir la "dictadura" de Balmaceda y hacer la defensa de

\footnotetext{
${ }^{34}$ R. B. Gumucio, (recopilación e introducción), Colección de discursos, T. II, 249-254.

${ }^{35}$ Abdón Cifuentes, Memorias, T. II,... 295.
} 
la constitucionalidad. ${ }^{36}$ Se formó entonces una comisión del partido conservador, compuesta por el propio Cifuentes y otros más, quienes se reunieron con representantes de los otros partidos políticos. Esta Junta de los partidos de oposición fue la que planeó la revolución. ${ }^{37}$ En los últimos días de diciembre de 1890, Cifuentes se vio conminado a redactar el acta de deposición del presidente Balmaceda, tan pronto como los anteriores comisionados no cumplieron con su cometido, unos porque no satisficieron los requerimientos que se había fijado, y otros porque lo rehusaron absolutamente. ${ }^{38}$ Luego de varias reuniones, el acta fue firmada por los miembros de la Junta y por todos los miembros del Congreso.

Cuando el presidente Balmaceda rompió el marco constitucional al iniciar el año de 1891 sin la aprobación del Congreso a la ley de presupuestos la guerra civil se precipitó. El 7 de enero inició con la sublevación de la marina, encabezada por el almirante Jorge Montt y acompañado de Ramón Barros Luco, presidente de la Cámara de Diputados y de Waldo Silva, vicepresidente del Senado. En tanto que el presidente Balmaceda decretó el estado de sitio, mandó perseguir y encarcelar a los opositores, hizo elegir un nuevo Congreso y reforzó al Ejército que le fue leal. ${ }^{39}$ La guerra civil duró nueve meses, desde su inicio en enero, hasta la renuncia de Balmaceda en septiembre de 1891. Durante ese tiempo Cifuentes permaneció escondido, pues aún cuando no era miembro del Congreso, formaba parte de la Junta opositora y por lo tanto era buscado por las fuerzas balmacedistas. Chillán, Concepción, Lota, Talca, Buin y Santiago, fueron los lugares en los que hubo de ocultarse Cifuentes en los meses

\footnotetext{
${ }^{36}$ Abdón Cifuentes, Memorias, T. II... 302.

${ }^{37}$ Don Abdón Cifuentes,... 16.

${ }^{38}$ Max Martínez M., Semblanzas chilenas,... 146.

${ }^{39}$ Nicolás Cruz y Pablo Whipple, Nueva historia de Chile,... 336.
} 
que duró el conflicto. ${ }^{40}$ Cuando éste concluyó, el retorno a la formalidad constitucional se dio de inmediato, pues se realizaron elecciones presidenciales. ${ }^{41}$ En la siguiente etapa, conocida en la historiografía chilena como el periodo republicano, Cifuentes continuó con sus actividades docentes y parlamentarias y el propio partido conservador escaló posiciones relevantes en los siguientes gobiernos. El ingreso al siglo XX le trajo numerosas mudanzas a Cifuentes, como la ausencia física de sus compañeros de ruta, nuevos desencuentros con los liberales, la conducción del partido conservador, la frustración de ver obstaculizado su anhelado proyecto de dotar a la enseñanza católica de mayores garantías. Cifuentes murió en 1928 en una época política distinta que, sin embargo, él mismo contribuyó a modelar. ${ }^{42}$

\section{Construyendo máquinas de guerra}

En 1862 Abdón Cifuentes ingresó a la redacción de $E l$ Bien Público semanario que había fundado y costeado Manuel José Irarrázaval ${ }^{43}$, uno de los principales líderes del partido conservador. ${ }^{44}$ Cifuentes se incorporó al equipo que integraban los presbíteros Joaquín Larraín Gandarillas, José Manuel Orrego y Zorobabel Rodríguez, quienes escribían bajo seudónimo, y él haría exactamente

\footnotetext{
${ }_{40}$ Abdón Cifuentes, Memorias, T. II,... 310-332.

${ }^{41}$ Simon Collier y W. F. Sater, Historia de Chile,... 171.

${ }^{42}$ Para una mirada de la evolución liberal del periodo véase: Iván Jaksic y Sol Serrano, "El gobierno y las libertades. La ruta del liberalismo chileno en el siglo XIX", en Liberalismo y poder. Latinoamérica en el siglo XIX (Santiago: FCE, 2011) 177- 206.

43 Véase: Francisco A. García Naranjo, Manuel José Irarrázaval, un conservador y combatiente por las libertades públicas, (Morelia: UPO/ UMSNH, 2007).

${ }^{44}$ Don Abdón Cifuentes,... 6.
} 
lo mismo. ${ }^{45}$ Él usó el seudónimo de C. Olivares ${ }^{46}$ hasta que su incógnita fue revelada por el juicio que se le siguió por supuesta difamación en octubre de 1863, cargo del que fue absuelto. ${ }^{47}$

Dice Cifuentes en sus Memorias que la tragedia del incendio en la iglesia de la Compañía en noviembre de 1863 (donde se perdieron numerosas vidas) trajo una campaña difamatoria contra la iglesia como institución y a la religión católica, orquestada por la prensa liberal y radical, que habló de las terribles consecuencias del "fanatismo religioso". Y que para afrontar esa "avalancha de impiedad"48, el equipo de redacción de El Bien Público llegó a la conclusión de que era necesaria la fundación de un diario católico que hiciera la defensa cotidiana de la religión y de las ideas conservadoras. Así, el $1^{\circ}$ de marzo de 1864 nació El Independiente ${ }^{49}$, con la importante aportación económica de Manuel José Irarrázaval y el concurso de muchos otros suscriptores, miembros de la élite chilena. Cifuentes Espinosa, aunque reticente a involucrarse de lleno en el "teatro revuelto de la política" ${ }^{50}$ pues ello le resultaba detestable y le apartaba de sus tareas docentes, litigantes y de estudio de la historia de Chile, también juzgaba como inexcusable su participación. Así lo expresó:

Como católico me sentía profundamente herido en mis más delicados sentimientos y en mis más caras convicciones, con el desbordamiento de impiedad $\mathrm{y}$ de malas pasiones que manifestaba la prensa

\footnotetext{
${ }^{45}$ Máximo R. Lira, "ligeros apuntes para la historia del periodismo católico en chile”, El Independiente, Santiago, $1^{\circ}$ de septiembre de 1872.

${ }^{46}$ Abdón Cifuentes, Memorias, T. I,... 72.

${ }^{47}$ Abdón Cifuentes, Memorias, T. I,... 72-80.

${ }^{48}$ Abdón Cifuentes, Memorias, T. I,... 90.

${ }^{49}$ El Independiente, Santiago, $1^{\circ}$ de marzo de 1864.

${ }^{50}$ Abdón Cifuentes, Memorias, T. I,... 37.
} 
liberal y radical. Soldado de la iglesia militante debía asociarme a sus luchas y a sus sacrificios, ya que deseaba tener parte en las recompensas prometidas a sus fieles hijos. ${ }^{51}$

Inevitablemente, Cifuentes dividió su tiempo entre el periodismo y la política, puesto que llevaba pocos años de ejercer su profesión de abogado y algunos más como profesor. Y es que ese convencimiento de defender la causa católica, atacada por las voces liberales lo apartó de forma irremediable de sus principales inclinaciones. El camino iniciado en el periodismo con El Bien Público se volvió una ruta de largo aliento con las labores de El Independiente. En un principio Cifuentes (al lado de Zorobabel Rodríguez), se mantuvo en puestos secundarios desde que inició la publicación del diario en marzo. Hubo sin embargo, cambios en la redacción del periódico en junio de $1864^{52}$ y en octubre del mismo año. ${ }^{53}$ Y luego de éste último, Cifuentes y Zorobabel Rodríguez se hicieron cargo de la redacción a principios de noviembre de 1864 .

Dada la circunstancia de ser ambos redactores del diario durante los primeros años de vida de $E l$ Independiente (1864-1867), difícil es determinar cuándo y quién escribía la columna editorial, pues no se firmaba en ese entonces. Sin embargo, queda claro que existía una misma mirada sobre la realidad político-social entre los hacedores del periódico de los conservadores. Con el tiempo, las visiones se volverían un poco divergentes. Tanto porque Cifuentes dejó el diario en 1867 para aceptar otras funciones, luego convertirse en promotor del diarismo católico e impulsor del asociacionismo también católico, como porque Zorobabel asumiría otros referentes

\footnotetext{
${ }^{51}$ Abdón Cifuentes, Memorias, T. I,... 91.

${ }^{52}$ El Independiente, Santiago, 21 de junio de 1864.

${ }^{53}$ El Independiente, Santiago, 31 de octubre de 1864.
} 
intelectuales que lo apartaría de la ruta - no del fin-, que Cifuentes y el resto de los conservadores seguían para la consecución de su idea de país. ${ }^{54}$

Por el propio Cifuentes, no obstante, se sabe de algunos de los editoriales que escribió en El Independiente, porque así lo dejó dicho en sus Memorias. Tal fue el caso de su propuesta del voto para la mujer en 1865 (como años más adelante lo sería con el posicionamiento del periódico sobre el decreto de libertad de exámenes, que él mismo confesó haber elaborado, luego de establecerlo como ministro de Instrucción). "Una cuestión importantísima de justicia, cuestión capital de democracia, cuestión de civilización"55; en esos términos se pronunciaba Abdón Cifuentes en el seno de la Sociedad de San Luis, a mediados de agosto de 1865 sobre lo que él llamaba el derecho electoral de la mujer. Esta fue la primera manifestación pública de ese tono liberalizante que definió la personalidad política de Abdón Cifuentes, pero sin abandonar el catolicismo. Prueba de ello es el hecho de ser señalado como el primer político en Chile en proponer públicamente la extensión del sufragio a la mujer ${ }^{56}$ en una época tan temprana, a la mitad del gobierno de José Joaquín Pérez (1861-1871). Eran también, los años de la Fusión Liberal Conservadora y del inicio del proceso de liberalización de la sociedad, muy a pesar del sentir conservador.

Ya Cifuentes apuntaba la incongruencia del marco normativo con el que se regía la sociedad chilena de la época. Para él la mujer tenía el pleno derecho de "tomar parte en la dirección de la cosa pública". Criterio

\footnotetext{
${ }^{54}$ Véase: Francisco A. García Naranjo, Zorobabel Rodríguez, un conservador moderno. Chile, 1864-1890 (Morelia: UMSNH, 2010).

${ }^{55}$ R. B. Gumucio, (recopilación e introducción), Colección de discursos, T. I,... 138.

${ }^{56}$ Erika Maza Valenzuela, "Catolicismo, anticlericalismo y la extensión del sufragio a la mujer en Chile”, Estudios Públicos: 58, (otoño de 1995): 153.
} 
que establecía a partir de su propia constatación de las capacidades concretas de las mujeres, lo mismo que del "interés legítimo" que ellas tenían por el "buen orden de la sociedad", así como por su "calidad de seres asociados" de una comunidad, y en función "a los deberes y cargas que el orden político" les imponía. ${ }^{57}$

$\mathrm{Y}$ es que, como declaró el editorialista de $E l$ Independiente, "a medida que ha ido creciendo la cultura de los pueblos, han ido también creciendo los derechos de la mujer". A los pocos días del discurso de Cifuentes en la Academia de San Luis, la columna editorial del diario conservador se ocupó del mismo tema en una serie de cinco partes, publicada entre el 22 y 27 de agosto de $1865 .{ }^{58} \mathrm{Se}$ trata de un mismo autor de tales escritos. Hecho que se corrobora al comparar ambos textos, los cuales presentan similitudes enormes, pero también diferencias, al ser ampliadas algunas argumentaciones contenidas en el discurso o al ser suprimidas ciertas afirmaciones que en el editorial ya no aparecen.

En la columna editorial de El Independiente se señaló que era en Austria donde se había concedido el derecho de voto a las mujeres mayores de edad "y libres administradoras de sus bienes" y que pagasen impuestos. Medio siglo de vida republicana en Chile, agregaba, debía bastar para ilustrar a la mujer en el significado del voto. Para ello, el editorialista conservador consideraba que el mejor camino era el aprendizaje paulatino y gradual:

Dad, pues, por grados a la mujer sus derechos políticos, y, dentro del mismo derecho electoral,

\footnotetext{
${ }^{57}$ Erika Maza Valenzuela, "Catolicismo, anticlericalismo y la extensión del sufragio",... 145.

${ }^{58}$ Cfr.: "El derecho electoral de la mujer I", El Independiente, 22 de agosto de 1865 .
} 
restringidlo al principio a muy determinadas personas e id dándole poco a poco mayor ensanche y extensión, y esa será la única manera de que la mujer realice y perfeccione su educación política (...) Que Chile dé en América el ejemplo de progreso en materia que, como hemos dicho, consideramos de la más profunda filosofía y de la más elevada perfección social. ${ }^{59}$

Como católico que era, Cifuentes creía en el sacrificio y en el cumplimiento del deber que le imponía su religión. Por eso había contribuido con su pluma en defensa de su fe. Entre 1862-1867 colaboró en la redacción de El Bien Público y El Independiente, periódicos que los miembros del partido conservador crearon para hacer la defensa del partido y de la religión católica. Así fue con El Bien Público (1862-1864) en el que participaron algunos religiosos y jóvenes laicos y, con El Independiente, ya sólo en manos laicas y colaboradores surgidos del partido conservador. Fue este diario en el que por una ruta separada de la iglesia, Cifuentes y Zorobabel Rodríguez (el otro redactor), dieron a conocer un ideario basado en el catolicismo, el republicanismo y el liberalismo, en una fusión no exenta de contradicciones.

Es decir, para los redactores y los financista del diario, se trataba de hacer política sí desde el catolicismo pero también con el instrumental de la política y sobre todo, con independencia de la iglesia. La conformación de la redacción de dicho periódico mostraba el espíritu con que se entendía la política por esos nuevos conservadores, y marcaría asimismo, el rumbo por el que se conduciría al partido, a la prensa del partido y a los parlamentarios del partido.

59 "El derecho electoral de la mujer V", El Independiente, Santiago, 27 de agosto de 1865 . 
Si bien el partido conservador se formó a partir del suceso del sacristán (1857) y sus integrantes se alinearon con el arzobispo Valdivieso y la iglesia ${ }^{60}$, la incorporación de Irarrázaval, Zorobabel, Walker, Cifuentes y muchos otros más que andando lo años se unirían, llevarían a esta colectividad a ser un partido organizado y dirigido por políticos, donde la jerarquía eclesiástica y la iglesia no tendría cabida ni injerencia. La iglesia y sus hombres no influirían en el partido conservador ni desde las alturas ni de forma soterrada. No fue así con la fundación de $E l$ Independiente, ni tampoco con el grupo de parlamentarios que a lo largo de las décadas se mantuvieron, aun cuando los propios conservadores en lo individual conservaran excelentes relaciones con eclesiásticos.

También fue verdad que El Independiente y eclesiásticos tuvieron un interés en común, como lo era la defensa del catolicismo, pero condujeron su defensa por rutas separadas y paralelas. Los conservadores combatieron los abusos del patronato que los gobiernos ejercían, sobre todos los liberales de las últimas décadas del siglo XIX. Defendieron la presencia de la iglesia en la sociedad por considerarla necesaria, y porque formaba parte de la esencia misma de lo social. Pero ello no implicó ningún tipo de intolerancia hacia otros credos, ni tampoco la imposición de los cánones católicos a aquellos que no los compartieran. Así lo proclamó el diario de los conservadores.

En sus columnas, el diario de los conservadores buscó redefinir el sitio del Estado y reformar el marco general del orden político. Y fue planteado de forma temprana, mucho antes de 1873 en que el partido conservador dejó el poder

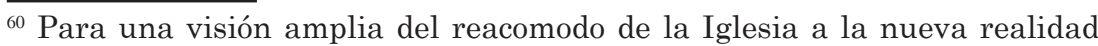
basada en el laicismo y la liberalización, véase: Sol Serrano, Qué hacer con Dios en la República? (Santiago: FCE, 2008). 
que compartía con los liberales. El Independiente entró en numerosas polémicas antes de 1870 con la prensa liberal y radical precisamente exponiendo su vocación reformadora y democrática, la cual era negada por los otros grupos políticos. Es decir, a los conservadores y a su periódico no se les reconocía su genuino liberalismo, su combate a las excesivas atribuciones del poder presidencial y propensión por el parlamentarismo.

De esa manera, entre 1864 y 1867 el diario que Cifuentes contribuyó a redactar declaró la necesidad política de la reforma constitucional. Los escritos en la prensa probaron una y otra vez que creían en las libertades. Por eso, proclamaron en El Independiente (y en el Congreso los parlamentarios del partido), la libertad electoral, proponiendo reformas avanzadas como la figura de los mayores contribuyentes para dirigir el proceso electoral y el voto acumulativo y las circunscripciones electorales. ${ }^{61}$ Zorobabel asimismo, apoyó desde 1872 la ampliación del sufragio. Igualmente Cifuentes se manifestó por la libertad de asociación y la libertad de enseñanza. Lo hizo en sus días como parte del equipo de redacción del diario y luego en 1872 lo llevó a cabo como ministro de Instrucción. Aunque llegaron a diferir en lo que podía ser el mejor camino para lograrlo, estos conservadores y el resto de sus correligionarios creían en la liberalización del sistema político a la vez que buscaban acotar las atribuciones del Estado. Por tanto, Cifuentes y Zorobabel en el diario combatieron el presidencialismo y la intervención electoral de que tanto se sirvieron los gobiernos liberales. Y lo hicieron aún cuando su partido estaba en el gobierno, como parte de la fusión liberalconservadora. ${ }^{62}$

${ }^{61}$ Nuestro programa”, El Independiente, Santiago, 27 de octubre de 1870.

62 "La conservación por la reforma", El Independiente, Santiago, 7 de abril de 1870 . 
Siendo ya diputado por Rancagua y a la vez subsecretario de Relaciones Exteriores, fundó el periódico La Estrella de Chile, como órgano oficial de la "Sociedad Amigos del País", en la que sus integrantes debían de aprender las artes del periodismo político para hacer una efectiva defensa del catolicismo. ${ }^{63}$ Dicha publicación apareció por primera vez en octubre de $1867^{64}$ y desapareció luego de 13 años. ${ }^{65}$ En las páginas de El Independiente se informó a los lectores de la inminente aparición de La Estrella de Chile, periódico semanal que, escribieron los redactores, venía a defender las mismas ideas que $E l$ Independiente, es decir, las ideas católicas. ${ }^{66}$ Así, el domingo 6 de octubre de 1867, apareció el primer número de $L a$ Estrella de Chile. Y de ello dio cuenta también el diario católico, que reprodujo en sus columnas el "Prospecto" del periódico:

Aunque los estudios literarios constituyan nuestro objeto primordial, no excusaremos ocuparnos, siquiera incidentalmente, de las cuestiones sociales y políticas a que vemos vinculados gravemente los destinos del país. Ni podríamos desentendernos de ellas, sin renunciar al amor y al interés que la patria inspira y sin faltar a los deberes que ella impone. La política nos interesa a todos por lo mismo que se roza con todo. Pero sean cuales fueren nuestras tareas, caminaremos siempre a la sombra de nuestra bandera, la bandera católica. Su ley es nuestra ley, su doctrina nuestra doctrina, su civilización nuestra civilización, su destino será nuestro destino: a su sombra nacimos y a su sombra moriremos, combatiendo por el bien y contra el mal.

\footnotetext{
${ }^{63}$ Abdón Cifuentes, Memorias, T. I,... 173.

${ }^{64}$ Don Abdón Cifuentes, 8. Otras fuentes, dan una fecha diferente. Véase: Sol Serrano e Iván Jaksic, "El poder de las palabras”,... 458.

${ }^{65}$ Abdón Cifuentes, Memorias, T. I,... 173.

${ }^{66}$ El Independiente, Santiago, 4 de octubre de 1867.
} 
No nos lisonjeamos ni tenemos la vanidad de hacer prosélitos; pero los que amen con entusiasmo la verdadera gloria ¿dónde encontrarán otra bandera más heroica y gloriosa que el catolicismo? Que vuelvan la vista a todos los tiempos y a todos los lugares, y en toda la prolongación de los primeros y en toda la inmensidad de los segundos ¿dónde está la escuela, la sociedad ni el partido, cuya bandera cuente en maravilloso conjunto ni los siglos, ni los sabios, ni los héroes, ni las virtudes, ni los combates que la bandera católica? Quién que respete la virtud y ame la gloria ¿no respetará ni amará la enseñanza gloriosísima del mártir del Gólgota? ${ }^{67}$

De acuerdo con Cifuentes, los redactores principales de La Estrella de Chile fueron miembros del partido conservador. ${ }^{68}$ Muchos de ellos, estuvieron vinculados a $E l$ Independiente como redactores o colaboradores del mismo, entregando piezas literarias, traducciones, poemas o relatos de viajes. Cifuentes fundó La Estrella de Chile, publicación dominical de contenidos literarios, políticos, católicos, históricos y sociales, como alternativa a los periódicos de corte liberal que circulaban ampliamente e ingresaban "impunemente" a los hogares católicos.

Poetas, periodistas y escritores, la intelectualidad del partido conservador, participaron en los contenidos de este periódico que buscaba llevar a las familias católicas una lectura amena y moral. La Estrella de Chile, que se mantuvo vigente por 12 años se imprimió en la tipografía de El Independiente. El objetivo de Cifuentes era generar una pedagogía civil y católica que formara e interesara a los católicos por las cosas de este mundo, no sólo que la impotente mayoría sufriera en privado los males sociales de su tiempo. La idea era que la grey católica expresara su

${ }^{67}$ Suplemento al Independiente (sic), Santiago, 7 de octubre de 1867.

${ }^{68}$ Abdón Cifuentes, Memorias, T. I,... 175. 
gran fuerza y número en la vida pública, en las elecciones y en el Parlamento, e inclinara la balanza de la toma de decisiones para detener "la avalancha de impiedad" traída por los liberales. O en generar mayores espacios y garantías constitucionales para la iglesia y a la sociedad católica que veían limitado o amenazado su campo de acción en ámbitos como los matrimonios, los cementerios, en la enseñanza, en el asociacionismo, en los derechos civiles y políticos de los eclesiásticos.

La labor de Cifuentes dentro del periodismo católico no se detuvo ahí, pues en los años siguientes colaboró en el sostenimiento del periódico semanal el Obrero Católico en Talca ${ }^{69}$ que se publicaba una vez a la semana ${ }^{70}$, del periódico El Verdadero Liberal de San Felipe ${ }^{71}$, de $E l$ Amigo del País en Copiapó del bisemanal La Libertad Católica ${ }^{72}$, y la Unión ${ }^{73}$ en Concepción. En el sostenimiento de todos estos diarios Cifuentes involucró a la red de la "Sociedad de Amigos del País" que se extendió a muchas ciudades, y luego de extinguida ésta, fueron las huestes de la Unión Católica (1883) las que tomaron en sus manos el sostenimiento de las publicaciones católicas.

Cifuentes se dedicó a otras tareas que para él eran importantes en la ruta de defensa de las creencias católicas, puesto que ya no continuó como diputado en las elecciones de $1876^{74}$, debido a la manipulación del proceso por los agentes

\footnotetext{
${ }^{69}$ Abdón Cifuentes, Memorias, T. I,... 176.

${ }^{70}$ El Independiente, Santiago, $1^{\circ}$ de octubre de 1867.

71 Abdón Cifuentes, Memorias, T. I,... 176.

${ }^{72}$ Máximo R. Lira, "ligeros apuntes para la historia del periodismo católico en chile”, El Independiente, Santiago, 1 de septiembre de 1872.

${ }^{73}$ Abdón Cifuentes, Memorias, 1936, T. I,... 315.

${ }^{74}$ Germán Urzúa Valenzuela, Historia política de Chile, 241. Cfr.: "los crímenes de ayer. La elección transformada en una verdadera batida contra los ciudadanos independientes", El Independiente, Santiago, 28 de marzo de 1876.
} 
del "gobierno radicalizado de Errázuriz". ${ }^{75}$ Así, Cifuentes se ocupó de la renovación de nuevas suscripciones para el mantenimiento de El Independiente, la construcción de un edificio propio para el diario y el establecimiento del primer Círculo Católico de la juventud ilustrada en Santiago, que venía a sustituir a la "Sociedad de Amigos del País". Tales objetivos se lograron en noviembre de $1876 .{ }^{76}$ Para entonces, ya había fundado otro diario católico, esta vez en Linares y que llevó el nombre de El Conservador. ${ }^{77}$ En enero de 1885, el Consejo Departamental de la Unión Católica en Valparaíso (asociación nacional que Cifuentes fundó con respaldo de la iglesia en 1833), auspició la publicación del diario La Unión, ${ }^{78}$ obra que el activista católico había manifestado como indiscutible para los intereses católicos. ${ }^{79}$ Es decir, Cifuentes prosiguió con la tarea de promover la organización de las fuerzas católicas del país, de impulsar la prensa católica y fomentar las asociaciones de la juventud y de los obreros. Y luego lo haría con la sociedad toda.

\section{Activismo católico-social}

En 1865 Abdón Cifuentes fundó la "Sociedad de los Amigos del País" ${ }^{80}$, institución que nacía de la profunda cavilación que le provocaba el avance político del liberalismo y el paulatino afianzamiento del laicismo, que los liberales

\footnotetext{
${ }^{75}$ Abdón Cifuentes, Memorias, T. II,... 121-127.

${ }^{76}$ Abdón Cifuentes, Memorias, T. II... 121.

${ }^{77}$ Don Abdón Cifuentes,... 12.

${ }^{78}$ Véase la columna editorial del diario La Unión que publicó El Independiente. "ideas y propósitos (de la Unión de Valparaíso)", El Independiente, Santiago, 24 de enero de 1885.

${ }^{79}$ Abdón Cifuentes, Memorias, T. II,... 223.

80 "Club de los Amigos del País", El Independiente, Santiago, 15 de agosto de 1865. Cfr.: Virgilio Figueroa, Diccionario histórico, biográfico y bibliográfico de Chile, (Santiago: Balcells \& CO., 1928) T. II, 404.
} 
exigían en forma ruidosa y cada vez más exaltada. Él lo puso en los siguientes términos:

Vínome luego al pensamiento la idea y al corazón el firme propósito de remediar ese mal, formando una sociedad donde agrupar a la juventud católica, donde adiestrarla para las luchas de la palabra y de la pluma, donde empujarla a la acción en los terrenos de la vida pública, donde, en fin, se acostumbrase a levantar valientemente el estandarte católico y a batir de frente el abultado fantasma de la impiedad. ${ }^{81}$

El mismo Cifuentes escribió en su Memorias que el nombre de la Asociación le fue sugerido por el arzobispo Rafael Valentín Valdivieso cuando fue a ver a éste para obtener su opinión y aprobación. El objetivo de Cifuentes fue el de organizar a la juventud católica y a jóvenes conservadores con el objetivo de entrenarlos en "las luchas de la palabra y de la pluma" ${ }^{2}$ y hacerlos participar en la vida pública, pues veía el avance del liberalismo y el laicismo tanto en el gobierno, el Congreso y en los debates de la opinión política, es decir, la prensa de la época. Un editorial de El Independiente dio a conocer el surgimiento de la "Sociedad de Amigos del País", que explicó la misión que se fijaba dicho club:

[...] Si no nos engañamos, su programa pudiera muy bien resumirse en estas palabras: orden, libertad y progreso, mediante la aplicación de los principios católicos. Los miembros del club llevarán sus simpatías y su apoyo hacia donde vean flamear esta bandera; pero ya sea que ella sea levantada por el Gobierno o por la oposición, jamás para sostenerla saldrán de la estricta órbita que la ley les prescribe. ${ }^{83}$

\footnotetext{
${ }^{81}$ Abdón Cifuentes, Memorias, T. I, 129.

${ }^{82}$ Abdón Cifuentes, Memorias, T. I, 129.

${ }^{83}$ El Independiente, Santiago, 15 de agosto de 1865.
} 
El 10 de septiembre de 1865 se celebró la primera Asamblea General de la Asociación "Amigos del País", con una asistencia cercana a los cien miembros. En ella se aprobaron los estatutos y se realizó la elección del Directorio que habría de encabezar las actividades en el primer año. ${ }^{84}$ Muchos de aquellos que ingresaron a la "Sociedad de Amigos del País" después pasaron a conformar el grueso del partido conservador. Luego de su regreso de Europa en 1871, Cifuentes reasumió la jefatura de la "Sociedad de Amigos del País" a la que involucró en la contienda presidencial que habría de elegir presidente a Federico Errázuriz (1871-1876), apoyado por la iglesia y los conservadores. Así, explicó en sus Memorias que se reunía con funcionarios de gobierno y conservadores para dirigir los trabajos electorales, que en su caso implicó enviar a miembros de la sociedad distintas localidades para fundar pequeños periódicos, organizar mítines y generar opinión a favor de Errázuriz en los meses previos a la elección. Y agregó:

El hecho fue que los "Amigos del País" desempeñaron en la campaña electoral el papel más brillante tanto en Santiago como en las provincias... Errázuriz resultó elegido por una gran mayoría y yo quedé muy satisfecho de haber experimentado en la práctica uno de los fines principales con que había fundado la Sociedad, cual era el empuje a los católicos a las luchas de la vida pública y combatir la abstención y dispersión en que acostumbraban vivir $[\ldots]^{85}$

Como ya se explicó en páginas previas, triunfante el liberal Errázuriz, pasaría poco tiempo para que esa sociedad entre liberales y conservadores se rompiera, dejando a los conservadores perplejos. Sin embargo, este conservador

${ }^{84}$ El Independiente, Santiago, 12 de septiembre de 1865.

${ }^{85}$ Abdón Cifuentes, Memorias, T. I,... 404. 
prosiguió con su ardua tarea, organizando las huestes católicas, alternando sus funciones como parlamentario e impulsor de la prensa católica y conservadora. Otras sociabilidades católicas fueron conformándose por impulso de Cifuentes entre 1876 y 1888, fundadas entre la juventud, la clase obrera y la propia élite. Así, entre 1874 y 1876 repartió el tiempo entre su cátedra en el Instituto Nacional, la abogacía y el cumplimiento de obras sociales y de caridad, tan importantes para su convicción católica. De ello dan testimonio la fundación de escuelas gratuitas en barrios pobres de Santiago, y la construcción del asilo de Santa Rosa en $1877 .{ }^{86}$ Otra gran tarea que emprendió Cifuentes fue la fundación de una asociación que congregara a los obreros y así, hacer que la Iglesia, el catolicismo y el partido conservador ganasen posiciones en el mundo popular:

El ostracismo político a que el Gobierno liberal y radical tenían condenado al partido conservador, alejado sistemáticamente de todos los puestos públicos; las diversas tentativas de persecución religiosa que se venía diseñando desde las discusiones del Código penal, nos venían revelando la imperiosa necesidad de prepararnos para las supremas luchas que habrían de venir tarde o temprano. De ahí mis anhelos con que desde años atrás venía trabajando por asociar a los católicos, estrechar sus filas, disciplinar sus fuerzas $\mathrm{y}$ adiestrarlos para las luchas de la vida pública. Ese fue el objeto de la Sociedad de los Amigos del País; ese era el fin que perseguía con la creación del Círculo Católico de la juventud ilustrada de la Calle de la Moneda. Pero teníamos como abandonado al pueblo obrero, apenas atendido en las sociedades de piedad. Era urgente llevar nuestra acción y nuestra

${ }^{86}$ Véase: R. B. Gumucio, (recopilación e introducción), Colección de discursos, T. II,... 163-188. 
influencia a esas masas populares, tan poderosas por el número y tan expuestas a la seducción de las malas doctrinas por su falta absoluta de preparación para resistir a ellas. Había yo conocido los círculos obreros fundados por el insigne canónigo Kolping, en Alemania y me había informado de los círculos obreros que, a imitación de aquellos, había comenzado a formar en Francia el Conde de Mun. Conforme a ellos, propuse al presbítero Ramón Ángel Jara, formásemos una asociación católica de obreros en Santiago, que pudiese enseguida extenderse a las provincias. ${ }^{87}$

El propósito de Cifuentes era el trascender la etapa del socorro y caridad para situarse en condiciones de emprender una "acción de proselitismo político-religioso ${ }^{88}$ entre la clase obrera. Así, Cifuentes y el presbítero Jara elaboraron los estatutos de Asociación Católica de Obreros los cuales establecían como objetivo el evangelizar, educar y hermanar a los obreros católicos. De la misma manera, disponían que cada Círculo Católico contase con escuela, biblioteca, sala de conferencias, áreas de recreo y diversión, así como una capilla. Respecto a sus miembros, éstos se dividirían en socios activos (quienes debían ser obreros mayores de 18 años, "católicos, apostólicos y romanos" y mostrar buena conducta), y socios protectores (aquellos que sin ser de la clase obrera pero que "como prendas de simpatía y protección a dicha clase" quisieran formar parte de la asociación). En dichos estatutos se acordaba que la dirección general de la Asociación recaía en un sacerdote y un laico, aprobados por el arzobispo de Santiago. ${ }^{89}$

\footnotetext{
${ }^{87}$ Abdón Cifuentes, Memorias, T. II,... 148-149.

${ }^{88}$ La expresión es de: Sergio Grez Toso, De la "regeneración del pueblo" a la huelga general. Génesis y evolución histórica del movimiento popular en Chile (1810-1890) (Santiago: Dibam, 1997) 532.

${ }^{89}$ Véase: Ramón Ángel Jara y Abdón Cifuentes, Estatutos de la Asociación de obreros, establecida en Santiago en 1878 (Santiago: Imprenta de El Independiente, 1878).
} 
La Asociación Católica de Obreros y sus estatutos fueron aprobados por la iglesia como deseaba Cifuentes. A finales de mayo de 1878 ya operaba. ${ }^{90} \mathrm{Y}$ aunque tuvo una corta vida, con serios altibajos, la Asociación como tal fue una prueba palpable del modo en cómo los sectores dirigentes de filiación conservadora o tradicional visualizaron el problema de la pobreza e igualmente, del papel social que le asignaban al obrero. En otras palabras, eran el clero y la élite conservadora quienes dirigirían a esta organización obrera en función de una "convocatoria político-ideológica tradicional"91, vertical y paternalista, desde la doble jerarquía de lo eclesiástico y lo social.

Con la ruptura de relaciones diplomáticas entre Chile y la Santa Sede a principios de 1883 por la expulsión del delegado apostólico que había llegado a Chile para zanjar las diferencias entre el gobierno del liberal Santa María (1881-1886) y el clero local respecto a la vacante en el arzobispado, se tensaron las relaciones iglesia-Estado. La despedida del enviado del Papa convocó a una multitud de católicas y católicos, lo mismo que sacerdotes que se reunieron en un banquete y en el que Cifuentes declaró, en un sentido discurso, la indignación que le provocaba tal hecho. ${ }^{92}$ En éste contexto fue en el que el clero y el círculo de fieles se organizaron para hacer la defensa activa de sus creencias religiosas. Y fue Cifuentes, por sus antecedentes y arraigadas convicciones religiosas, el operador sociopolítico capaz de encabezar semejante empresa. El detonante fueron las medidas materiales que el gobierno tomó como respuesta a la beligerancia del clero y las amenazas espirituales que ello suponía. Escribió Cifuentes:

\footnotetext{
${ }^{90}$ El Independiente, Santiago, 29 de mayo de 1878.

${ }^{91}$ Sergio Grez Toso, De la "regeneración del pueblo" a la huelga general,... 527.

${ }^{92}$ R. B. Gumucio, (recopilación e introducción), Colección de discursos, T. II, ... 61-64.
} 
Cuando volví de Valparaíso a principios de marzo [de 1883], el señor [Joaquín] Larraín, que gobernaba la Arquidiócesis, en calidad de Vicario Capitular, me llamó a su casa y me dijo: 'El Gobierno me ha negado la renta de Vicario y la subvención a los seminarios, a pesar de estar consignadas en el presupuesto, es decir, comienza las hostilidades a la Iglesia, con que amenazó a Mgr. del Fratte. Creo indispensable convocar a los católicos, exhortarlos a que acudan a la defensa de sus intereses religiosos y organizarlos de alguna manera, a fin de que su defensa sea eficaz, y he pensado que usted podía ayudarme a realizar este deseo'. 'Tal vez, le contesté, convendría formar en Chile la Unión Católica, a semejanza de las sociedades que con ese nombre y con idénticos propósitos se formaron en Alemania, Bélgica E Inglaterra. En los Boletines que tengo en las grandes asambleas que los católicos de Europa, celebraron en Bélgica en los años de 1863, 64 y 67 he podido conocer mucho de eso. Tengo también algo de lo que se ha hecho con el mismo objeto en Francia y España. Eso podría servirnos de norma'. 'Perfectamente, me dijo, estudie esos antecedentes $\mathrm{y}$ vea si puede formularme los Estatutos de alguna sociedad encaminada al objeto que le he indicado.'. ${ }^{93}$

Cifuentes elaboró los Estatutos de lo que sería la Unión Católica, los cuales fueron aprobados por la jerarquía eclesiástica en junio de 1883. Este sólo fue el inicio de la ardua tarea que implicó dotar a la Unión Católica de bases generales para organizarse y operar. ${ }^{94}$ Se generaron estructuras tales como el Consejo General, de los Consejos Departamentales, de los Consejos de Subdelegación y de las Juntas de Señoras. Cifuentes fue electo presidente del Consejo General. Dos fueron los acuerdos que se tomaron

\footnotetext{
${ }^{93}$ Abdón Cifuentes, Memorias, T. II,... 175-176.

${ }^{94}$ R. B. Gumucio, (recopilación e introducción), Colección de discursos de don Abdón Cifuentes, 13.
} 
en la sesión constitutiva: hacer la defensa y propagación de los principios y obras católicas y, que la Unión Católica siempre obraría con acuerdo de la jerarquía eclesiástica. ${ }^{95}$

Por su parte, en agosto de $1883^{96}$ el gobierno de Santa María promulgó la ley de cementerios laicos. ${ }^{97} \mathrm{La}$ autoridad eclesiástica en respuesta los execró y el gobierno se vio obligado a usar la fuerza para hacer cumplir la ley. Esta tensión política y religiosa provocó uno de los episodios más singulares en la batalla entre la iglesia y el Estado liberal, quedando en el medio los ciudadanos que a la vez eran los fieles. Frente a ésta situación, los católicos no deseaban enterrar a sus muertos en los cementerios laicos, ya que la iglesia había decretado que no eran más tierra bendita y, por tanto, buscaron los medios para burlar la vigilancia policial y llevar a sus difuntos a los pocos cementerios católicos que quedaban en manos particulares. Esto trajo numerosos persecuciones y demasiados hechos lamentables y grotescos, que un testigo de la época calificó como la "página más negra de nuestros anales históricos". ${ }^{98}$ Cifuentes afirma en sus Memorias que esos atroces sucesos provocaron la indignación general y trajeron el enrolamiento en la Unión Católica, pues como nunca, se “despertó el adormecido espíritu de los católicos". ${ }^{99}$

El de 1884 fue un año fructífero para el activismo católico de Cifuentes. En abril se inauguró un círculo de obreros que llevó por nombre Círculo de Santo Domingo. ${ }^{100}$

\footnotetext{
${ }^{95}$ Abdón Cifuentes, Memorias, T. II,... 177-180.

96 "Decreto que organiza provisoriamente el registro de defunciones", El Independiente, Santiago, 15 de agosto de 1883.

${ }^{97}$ Nicolás Cruz y Pablo Whipple, Nueva historia de Chile,... 230.

${ }_{98}$ Carlos Walker Martínez, Historia de la administración Santa María (Santiago: Imprenta de "El Progreso", 1889) T. I, 195.

${ }^{99}$ Abdón Cifuentes, Memorias, T. II,... 181.

${ }^{100}$ Abdón Cifuentes, Memorias, T. II,... 209.
} 
Por esta misma labor de Cifuentes, en el mes de junio se formaron un Círculo Católico de Obreros en Valparaíso ${ }^{101}$ y otro en San Felipe ${ }^{102}$, su tierra natal. En septiembre, Cifuentes y otros más dejaron concluidos los estatutos de la Sociedad Unión Central que debía ser el "ministerio de hacienda de las obras" de la Unión Católica. ${ }^{103}$ Desde ese mismo mes, Cifuentes se dedicó por entero a los preparativos para la celebración de asamblea de la Unión Católica que tuvo lugar en Santiago del $1^{\circ}$ al 4 de noviembre de 1884. ${ }^{104}$ Cifuentes pronunció el discurso central de la Asamblea ${ }^{105}$, que tuvo la asistencia de miles de personas. Los temas que se trataron fueron: instituciones de piedad y caridad; publicaciones católicas; asociaciones católicas; instrucción; intereses, derechos y libertades religiosas. ${ }^{106}$ En enero de 1885, viajó a Talcahuano para fundar el Consejo Departamental de la Unión Católica y la Junta de Señoras. ${ }^{107}$ Es decir, Cifuentes proseguía con la tarea de promover la organización de las fuerzas católicas del país, de impulsar la prensa católica y fomentar las asociaciones de la juventud y de los obreros.

La segunda gran Asamblea de la Unión Católica se celebró entre el $1^{\circ}$ y el 5 de noviembre de 1885 y el discurso de apertura lo dio Abdón Cifuentes. ${ }^{108}$ En verdad Cifuentes se dedicó de lleno al activismo del asociacionismo católico,

\footnotetext{
${ }^{101}$ Abdón Cifuentes, Memorias, T. II,... 208.

102 Abdón Cifuentes, Memorias, T. II,... 212.

${ }^{103}$ Abdón Cifuentes, Memorias, T. II,... 211.

104 "La gran asamblea católica de ayer. Más de cuatro mil asistentes. Espléndidas manifestaciones", El Independiente, Santiago, 2 de noviembre de 1884.

${ }^{105}$ R. B. Gumucio, (recopilación e introducción), Colección de discurso de don Abdón Cifuentes, t. II, 133-156.

${ }^{106}$ Abdón Cifuentes, Memorias, T. II,... 223.

${ }^{107}$ Abdón Cifuentes, Memorias, T. II,... 226.

${ }^{108}$ R. B. Gumucio, (recopilación e introducción), Colección de discurso de don Abdón Cifuentes, T. II, 189-206.
} 
pues estuvo convencido de que esta opción sociopolítica era una ruta tan importante como el parlamento para detener la “opresión” del Estado liberal. Así lo escribió:

Yo no era diputado desde el año 82. Mis amigos me habían ofrecido algunas diputaciones; pero yo las rehusé porque eran absolutamente incompatibles con el enorme trabajo que me imponían mi profesorado, mi abogacía y, sobre todo, la Unión Católica, que me absorbía casi todo mi tiempo como su presidente general y como presidente del Círculo Católico de Obreros. Así es que mientras mis compañeros luchaban en el Congreso, yo reclutaba soldados, los disciplinaba y adiestraba para las luchas de la vida pública y trataba de formar en todas partes centros de acción social católica que con el tiempo pudiesen contener las persecuciones del Gobierno. ${ }^{109}$

A principios de 1886 Cifuentes viajó a Ancud y luego a Puerto Montt, y en ambos sitios creó los correspondientes Consejos Departamentales y las Juntas de Señoras. En Puerto Montt, además, auspició la fundación de un periódico católico llamado El Llanquihue. ${ }^{110}$ En agosto, Cifuentes inauguró un nuevo círculo católico en Santiago. ${ }^{111}$ $\mathrm{Y}$ en diciembre de 1886, en el marco de la tercera asamblea general de la Unión Católica, Cifuentes renunció a su presidencia, aduciendo los efectos en su salud de la carga excesiva de trabajo. Ahí pronunció su último discurso como presidente de la Unión Católica. ${ }^{112}$

\footnotetext{
${ }^{109}$ Abdón Cifuentes, Memorias, T. II,... 244.

${ }^{110}$ R. B. Gumucio, (recopilación e introducción), Colección de discursos de don Abdón Cifuentes, T. I, 14.

${ }^{111}$ Abdón Cifuentes, Memorias, T. II,... 249.

${ }^{112}$ R. B. Gumucio, (recopilación e introducción), Colección de discursos de don Abdón Cifuentes, T. II, 217-224.
} 
Para 1887 ya había finalizado la batalla que se originó con la vacante en el cargo de arzobispo de Santiago. El nuevo gobierno del liberal José Manuel Balmaceda (1886-1891) restableció las relaciones diplomáticas entre el Vaticano y el gobierno de Chile. ${ }^{113}$ Después de años turbulentos en las relaciones entre la iglesia y el Estado liberal, el nuevo arzobispo de Chile deseaba desactivar al catolicismo beligerante que representaba la Unión Católica, por lo que no le dio continuidad. ${ }^{114}$ Cifuentes, sin embargo, por temperamento y convicciones políticas, no podía pensar en el mismo sentido que el arzobispo. No obstante, Cifuentes también era un hombre respetuoso de la jerarquía eclesiástica y de sus mandatos, es decir, él era un católico institucional. Toda su vida dio prueba de ello. Convencido entonces del fin de la Unión Católica, decidió que, pese a todo, quedaba algo más por hacer, fundar la Universidad Católica. ${ }^{115}$

El arzobispo Casanova, sin embargo, rechazó el ofrecimiento por considerar irrealizable el proyecto de una Universidad católica. ${ }^{116}$ Aunque, luego de una reunión con las principales figuras del clero chileno, accedió a la creación de la Universidad. Así, el 21 de junio de 1888 el arzobispo decretó la fundación de la Universidad Católica. El 8 de septiembre de 1888 se llevó a cabo una solemne Asamblea General en el gran salón de la Unión Central ${ }^{117}$ para dar a conocer a los católicos los propósitos de la Universidad

\footnotetext{
${ }^{113}$ Ricardo Krebs W., La Iglesia de América Latina en el siglo XIX (Santiago: Ediciones Universidad Católica de Chile, 2002) 251.

${ }^{114}$ Abdón Cifuentes, Memorias, T. II,... 263-264.

${ }^{115}$ Abdón Cifuentes, Memorias, T. II,... 265.

${ }^{116}$ Ricardo Krebs W., et al., Historia de la Pontifica Universidad Católica de Chile, 1888-1988, (Santiago: Ediciones Universidad Católica de Chile, 2004), T. I, 15.

117 "Solemne asamblea para iniciar los trabajos de la Universidad Católica celebrada en el gran salón de la Unión Central, el 8 de septiembre de 1888", El Independiente, Santiago, 9 de septiembre de 1888.
} 
Católica. En la Asamblea hubo varios oradores y entre ellos Abdón Cifuentes. El tema que tocó Cifuentes fue el de la enseñanza industrial, vieja aspiración suya:

Es preciso fundar en una vasta escala y de una manera científica la enseñanza social del pueblo; es preciso abrir nuevos y variados horizontes a sus vocaciones de actividad y trabajo, es preciso multiplicar los medios de ganar la vida a esos millares de jóvenes que serían perversos literatos, pero que pueden ser verdaderos genios de la industria. Menos compendios de enciclopedias ambulantes y más trabajo, menos retórica y más industria, menos sofistas y más ingenieros, menos teorías y más ciencias aplicadas; eso es lo que este país nuevo y laborioso necesita para acrecentar su riqueza, su prosperidad, su bienestar. ${ }^{118}$

El 31 de marzo de 1889 se hizo la inauguración oficial de los cursos de la Universidad Católica. Las clases dieron inicio al día siguiente, $1^{\circ}$ de abril. Cifuentes fue nombrado profesor de derecho constitucional y, al lado de eclesiásticos y laicos, varios de ellos ligados al partido conservador, formaron en conjunto la planta docente y administrativa de la universidad. De esa manera, el político conservador que encabezó numerosas batallas para resistir al poder liberal, empeñó ahora sus esfuerzos al proyecto de la Universidad Católica, que fue otra forma de hacer frente a lo que consideraba las arbitrariedades del laicismo estatal.

${ }^{118}$ Citado en: Ricardo Krebs W., et al., Historia de la Pontifica Universidad Católica de Chile, T. II, 225-238. Véase también: El Independiente, Santiago, 9 de septiembre de 1888. 


\section{Conclusiones}

Como político, Cifuentes fue la suma del catolicismo y la modernidad político-liberal. Es decir, el catolicismo y el liberalismo fueron las dos influencias que conformaron la mentalidad y el comportamiento de este conservador. Nunca buscó una recomposición del papel central de lo religioso en la sociedad sino más bien, propició una relación moderna de la religión con el todo social. Es decir, en conformidad a los principios de la modernidad liberal que deseaba, la de potencias occidentales constitucionales como los Estados Unidos. Aunque no obstante, Cifuentes fue un político conservador muy cercano a los hombres de la iglesia, con los cuales se mantuvo en constante comunicación y a quienes consultaba en materias religiosas y espirituales. Pese a ser hombre muy institucional respecto a la obediencia y respeto a iglesia y su jerarquía, tampoco se podía decir que abdicaba de la observancia de las instituciones republicanas, pues era bastante moderno y sensato.

Como hombre público, este conservador partió del catolicismo y nunca lo abandonó en su vida. Fue liberal por convencimiento, en el mismo grado en que era católico por convicción. Desde su incorporación a la sociedad de "Los Amigos del País" (1865) apuntó categóricamente su catolicismo. En aquellos años, declaró reiteradamente ser un católico que asumía el deber de participar en la vida pública para defender su fe. Igualmente ya incorporado al Congreso, Cifuentes haría notar su liberalismo en materias como la electoral, el asociacionismo y la educativa. En estas áreas tuvo como referente al liberalismo norteamericano e inglés, pues en ellos encontraba la materialización de todas sus aspiraciones. Recordaba con beneplácito el pluralismo y la democracia en Estados Unidos, lo mismo que la libertad de enseñanza. 
La politización de la fe fue la gran estrategia de Cifuentes. En esta misión autoimpuesta fue un sobresaliente adalid en el ámbito de lo público y desde las instancias de lo ciudadano y lo civil que su perseverancia construyó a lo largo de los años. Su catolicismo de combate lo impulso a redactar y fundar diarios por todo el país durante décadas para pelear por la sociedad, construir ciudadanos y empujarlos a la lucha política en defensa del catolicismo. Por eso también se dedicó a organizar a los católicos: a la juventud, a los obreros, a la élite. Aquí, la misión era constituir una sociedad civil católica y opinante para que se hiciera presente en las elecciones, los congresos y los gobiernos para combatir el "furor demagógico" y el anticlericalismo de los liberales en el poder. Más adelante, frente a las leyes teológicas del gobierno de Santa María (1881-1886), fue pieza importante para organizar la indignación católica en la sociedad, para beneplácito de la iglesia. En muchos sentidos, Cifuentes fue un adelantado a su tiempo, pues anticipó muchos de los pasos dados por la iglesia católica en el siglo XX, tales como la creación de diarios propios, la organización especializada de los fieles y la construcción de ciudadanos por la vía de la enseñanza, mismos que habría de convertirse en diques al poderoso e imparable avance del laicismo.

\section{Fuentes Documentales}

El Independiente, Santiago, 1864-1890.

\section{Bibliografía}

Cifuentes, Abdón. Memorias. Santiago: Editorial Nascimento, 1936, 2 Tomos.

Las asociaciones católicas. Santiago: Imprenta de El Independiente, 1883. 
Colección de discursos de don Abdón Cifuentes. Santiago: establecimiento poligráfico Roma, 1897-1898.

Collier, Simon, W. F. Sater. Historia de Chile. 1808-1994. España: Cambridge University Press, 1998.

Cruz, Nicolás, Pablo Whipple, (coordinadores). Nueva historia de Chile. Desde los orígenes hasta nuestros días. Santiago: Zig-Zag, 1997.

García Naranjo, Francisco A. Manuel José Irarrázaval, un conservador y combatiente por las libertades públicas. Chile, 1861-1891. Morelia: UPO/UMSNH, 2007.

Zorobabel Rodríguez, un conservador moderno. Chile, 1864-1890. Morelia: UMSNH, 2010.

Donoso, Ricardo. Las ideas políticas en Chile. México: FCE, 1946.

Don Abdón Cifuentes: homenaje a su memoria. Santiago: Editorial La Ilustración, 1928.

Encina, Francisco A. Historia de Chile: texto original completo. Santiago: Editorial Nascimento, 20 Tomos, 1940.

Figueroa, Virgilio. Diccionario histórico, biográfico y bibliográfico de Chile, Santiago: Balcells \& Co., 1928, 6 tomos.

Gumucio, R. B., (recopilación e introducción). Colección de discursos de don Abdón Cifuentes. Santiago: Establecimiento Poligráfico Roma, 1897-1898, II Tomos.

Grez Toso, Sergio. De la "regeneración del pueblo" a la huelga general. Génesis y evolución histórica del movimiento popular en Chile (1810-1890). Santiago: Ediciones de la Biblioteca Nacional de Chile, 1997. 
Abdón Cifuentes, un publicista católico frente al Estado liberal. ...

Jaksic, Iván, Sol Serrano, "El gobierno y las libertades. La ruta del liberalismo chileno en el siglo XIX” (capítulo VII). En: Liberalismo y poder. Latinoamérica en el siglo XIX. Santiago: FCE, 2011.

Jara, Ramón Ángel, Abdón Cifuentes. Estatutos de la Asociación de obreros, establecida en Santiago en 1878. Santiago, Imprenta de "El Independiente", 1878.

Krebs W., Ricardo. La Iglesia de América Latina en el siglo XIX. Santiago: Ediciones Universidad Católica de Chile, 2002.

. M. A. Muñoz, P. Valdivieso. Historia de la Pontificia Universidad Católica de Chile, 1888-1988. Santiago: Ediciones Universidad Católica, 2004, 2 Tomos.

León León, Marco Antonio. Sepultura sagrada, tumba profana. Los espacios de la muerte en Santiago de Chile, 18831892. Santiago: Dibam, 1997.

Maza Valenzuela, Erika, "Catolicismo, anticlericalismo y la extensión del sufragio a la mujer en Chile", Estudios Públicos 58, (otoño de 1995): 137-197.

Martínez M., Max. Semblanzas chilenas. Primera serie, Próceres pelucones. Santiago: Imprenta La Cruz, 1948.

Serrano, Sol. Universidad y nación. Chile en el siglo XIX. Santiago: Editorial Universitaria, 1994.

. Iván Jaksic, "El poder de las palabras: la Iglesia y el Estado liberal ante la difusión de la escritura en el Chile del siglo XIX". Historia 33, (2000): 435-460.

Santiago, FCE, 2008.

Urzúa Valenzuela, Germán. Historia política de Chile y su evolución electoral (desde 1810 a 1992). Santiago: Editorial Jurídica de Chile, 1992. 
Walker Martínez, Carlos. Historia de la administración Santa María. Santiago: Imprenta de "El Progreso", 1889, 2 tomos.

\section{Citar este artículo:}

Francisco Alejandro García Naranjo, "Abdón Cifuentes, un publicista católico frente al Estado liberal. Chile, 1862-1890”, Revista Historia y Memoria, No. 08 (enero-junio, 2014), pp. 295-336. 